\title{
Preterm prelabour rupture of membranes (PPROM) and pregnancy outcomes in association with HIV-1 infection in KwaZulu-Natal, South Africa
}

\author{
Chidebere E. Onwughara, Dhayendre Moodley*, Nthabiseng Valashiya and Motshedisi Sebitloane
}

\begin{abstract}
Background: SubSaharan Africa has a disproportionate burden of HIV and preterm births (PTB). We hypothesized that PTB in HIV-1 infected women are more likely a result of prelabour rupture of membranes (PROM) and could lead to worse birth outcomes than HIV-uninfected women. We also hypothesized that PPROM increased the risk of mother-to-child transmission (MTCT) of HIV-1. Current clinical management protocols for PPROM do not include a differential treatment plan for HIV-infected women.

Methods: The maternity register at a regional hospital in a high HIV-burden district in South Africa was reviewed to identify all preterm births over a 3 month-period in 2018. We determined the incidence of PPROM using predefined criteria. Maternal age, parity, previous pregnancy complications, antenatal care, body mass index, history of smoking or alcohol, HIV infection and syphilis were computed on chi-square contingency tables to determine risk of PPROM. Overall pregnancy outcomes that included mode of delivery, fetal survival, birth weight, gestational age and newborn apgar scores were compared between HIV-infected and HIV-uninfected women whose pregnancies were complicated by PPROM. HIV-exposed newborns are routinely tested at birth for HIV by PCR.
\end{abstract}

Results: A total of 1758 deliveries were recorded for Jan-Mar, 2018, and 295 (16.8\%) were preterm. Maternity charts were retrieved for 236 (80.0\%) PTB; 47 of PTB (19.9\%; 95\% Cl 15.0-25.6) were further complicated by PROM which translates to $2.7 \%(95 \% \mathrm{Cl} 1.9-3.4)$ of all deliveries. None of the risk variables including HIV-positive status (48.9\% vs 47.6\%) were different between PPROM and non-PPROM groups and the majority of women were receiving CART (94.7 and 92.0\%). There were no differences in the proportion of low birth weight (RR $1.295 \% \mathrm{Cl} 0.6-2.1$ ) or severe preterm birth (RR 1.6; 95\% CI 0.9-2.9) between HIV-infected and HIV-uninfected women whose pregnancies were complicated by PPROM. None of the $22 \mathrm{HIV}$-exposed newborns in the PPROM group were HIV-infected at birth.

Conclusion: The PPROM incidence is not higher among HIV-infected women and our findings suggest that HIVinfected women who are virally suppressed on CART and presenting with PPROM are less likely to transmit HIV to their infants and do not have worse birth outcomes than HIV-uninfected women.

Keywords: HIV-1, Preterm birth, Prelabour rupture of membranes, Pregnancy outcomes

\footnotetext{
* Correspondence: moodleyd1@ukzn.ac.za

Department of Obstetrics and Gynaecology, School of Clinical Medicine,

University of KwaZulu-Natal, Durban, South Africa

C C The Author(s). 2020 Open Access This article is licensed under a Creative Commons Attribution 4.0 International License, which permits use, sharing, adaptation, distribution and reproduction in any medium or format, as long as you give appropriate credit to the original author(s) and the source, provide a link to the Creative Commons licence, and indicate if changes were made. The images or other third party material in this article are included in the article's Creative Commons licence, unless indicated otherwise in a credit line to the material. If material is not included in the article's Creative Commons licence and your intended use is not permitted by statutory regulation or exceeds the permitted use, you will need to obtain permission directly from the copyright holder. To view a copy of this licence, visit http://creativecommons.org/licenses/by/4.0/. The Creative Commons Public Domain Dedication waiver (http://creativecommons.org/publicdomain/zero/1.0/) applies to the data made available in this article, unless otherwise stated in a credit line to the data.
} 


\section{Background}

Sub-Saharan Africa carries a disproportionate burden of HIV and preterm births before 37 completed weeks of gestation [1-3]. Preterm births in developing countries are largely classified as spontaneous preterm births due to spontaneous onset of labour or prelabour premature rupture of membranes (PPROM) [4] and PPROM is known to complicate $3 \%$ of all pregnancies and contributes to a third of all preterm births [5, 6]. Globally, preterm births are known to contribute to $50 \%$ of neonatal deaths and associated with long-term neurodevelopmental impairment among surviving neonates [2]. In South Africa, preterm labour was reported to be the main cause of nearly $23 \%$ of perinatal deaths $(>500 \mathrm{~g}$ ) [6]. The most common risk factors for PPROM are cervicovaginal infections leading to chorioamnionitis, urinary tract infections, substance abuse including smoking, uterine distention and cervical incompetence [7-9]. Although HIV-1 infection is a well-documented risk factor for preterm births [10-13], there are not many studies that explored the association between HIV-1 infection and PPROM. In the pre-ARV era, HIV-1 in South Africa was associated with a higher rate of spontaneous preterm births [14], The aetiology of this association is not well understood, and it is also not clear whether these preterm births associated with HIV-1 were due to spontaneous preterm labour or PPROM.

Prolonged rupture of membranes in HIV-infected treatment-naïve pregnant women is a known risk for mother-to-child transmission of HIV $[15,16]$. There are only 2 studies that reported on MTCT rates in women whose pregnancies were complicated by PPROM, and no MTCT was reported in women on cART with PPROM $[17,18]$.

Management protocols for PPROM independent of HIV-status in developing countries have remained conservative and are solely guided by the gestation at which PPROM occurs. Further evidence of the impact of HIV1 infection on PPROM outcomes and MTCT is needed for treatment protocols to be reviewed.

We hypothesized that HIV-infected pregnant women are at an increased risk for PPROM and adverse birth outcomes when compared to HIV-uninfected women who deliver preterm. We also hypothesized that motherto-child transmission of HIV-1 was more likely to occur in preterm births complicated by prelabour rupture of membranes (PROM) than preterm births not complicated by PROM.

\section{Methods}

The maternity register at King Edward VIII Hospital $(\mathrm{KEH})$, a tertiary hospital in Durban, KwaZulu Natal was reviewed to identify all preterm births that occurred over a 3 month-period (January 1st and March 31st, 2018).
KEH provides general obstetric services to the local catchment population within a $10 \mathrm{~km}$ radius but also serves as a referral facility for high risk pregnancies such as previous caesarean sections, multiple pregnancies, hypertension, and diabetes seen at local primary health clinics. Women presenting with PPROM $<34$ weeks to local MOUs or clinics are referred to KEH. This being an exploratory study to determine the incidence of PPROM at this facility with a delivery rate of 600 per month, antenatal HIV prevalence of 40 and $12 \%$ preterm births, we chose to investigate all preterm births over a 3 -month period. The maternity charts of women who delivered before completing 37 weeks of gestation during the period were sought and obstetric history, patient demography, clinical data and pregnancy outcomes were extracted for all women who delivered between 24 and 36 weeks and 6 days of gestation. Gestational age was estimated either by the last normal menstrual date, early ultrasound before 24 weeks, or when these were not available, by late ultrasound. Pregnancy outcomes included stillbirths, early neonatal outcome and birth weight. HIV-related clinical characteristics included maternal CD4 count, antiretroviral treatment and HIV status of the newborn.

Pregnancy losses or spontaneous rupture of membrane before 24 completed weeks of gestation were excluded. PPROM was defined as spontaneous ruptured membrane at least one hour before onset of labour occurring before 37 weeks.

The study was approved by the Institutional Review Board of the University of KwaZulu-Natal.

Data were analysed using IBM SPSS Statistics for Windows, Version 26.0. (Armonk, NY). Ninety-five (95) \% confidence intervals were constructed around incidence point estimates i.e. incidence of PPROM for generalizability of findings to all deliveries at this facility. We tested for normal data distribution using the Shapiro-Wilk test. With continuous variables that were not normally distributed, we report the median and IQR. Differences in frequencies of categorical demographic or clinical characteristics and birth outcomes by PPROM and HIV status were assessed using the Pearson chi-square $\left(x^{2}\right)$ test or Fisher's exact test if an expected cell count contains fewer than 5 observations. Odds ratio and 95\% confidence intervals were calculated for categorical variables. An alpha value of 0.05 was considered significant.

\section{Results}

A total of 1758 deliveries were recorded between January 1st and March 31st, 2018, and 295 (16.8\%) were preterm. For this analysis, only the preterm deliveries were included. Complete maternity charts were retrieved for $236(80.0 \%)$ women who delivered $<37$ weeks gestation. Using the limited data from the maternity register (gestational age at delivery, maternal age, HIV status, mode 
of delivery, birth outcome and birth weight), patients whose maternity charts were not available were comparable to patients included in this analysis. The HIV prevalence in the 236 women who delivered preterm was $48.5 \%$ (95\%CI 41.9-55.1) and 92.5\% (95\%CI 85.8-96.7) of the 113 HIV-infected women were on antiretroviral treatment at the time of delivery.

Based on predefined criteria, 47 (19.9\%; 95\%CI 15.025.6) women presented with preterm prelabour rupture of membranes (PPROM) which translates to $2.7 \%$ (95\%CI 1.9-3.4) of all deliveries.

Women with PPROM did not differ from women without PPROM in age, parity and marital status (Table 1). The proportion of women with PPROM with previous pregnancy complications was higher than in the nonPPROM group (71.9\% vs $53.1 \%)$ but did not attain statistical significance $(p=0.072)$. The antenatal booking status $(89.4 \%$ vs $93.6 \%)$ and mean gestational age at booking (20.6 vs 18.5 weeks) were not significantly different in either PPROM or non-PPROM groups (Table 1). There was a large difference in proportions of women with a history of smoking between the PPROM and non-PPROM groups but this was not statistically significant. And there were no statistically significant differences in other modifiable risk factors such as BMI and alcohol consumption in the PPROM and non-PPROM groups. Of the 47 PPROM cases, $23(48.9 \%)$ vs 90 (47.6\%) of the non-PPROM cases were HIV-infected $(p=1.00)$.

While there were no stillbirths in the PPROM group, there were $28(15 \%)$ stillbirths in the non-PPROM group $(p<0.05)$ (Table 2). The proportion of infants weighing $<$ $2500 \mathrm{~g}$ or born $<34$ weeks of gestation was also significantly higher in the non-PPROM group when compared to the PPROM group. The proportion of stillbirths in the non-PPROM group was similar between HIV-infected and HIV-uninfected women $(16.9 \%$ vs $15.8 \% ; p=1.000)$ (Table 3). Other adverse birth outcomes in the nonPPROM group such as low birth weight $(<2500 \mathrm{~g})$, very preterm birth $(<34$ weeks) and low Apgar scores were more frequent among HIV-uninfected women than HIVinfected women but not attaining statistical difference (Table 3). There were no differences in the proportion of low birth weight (OR $1.095 \% \mathrm{CI} 0.3-3.4$ ) or severe preterm birth (OR 3.2; 95\%CI 0.9-10.7) between the HIVinfected and HIV-uninfected women whose pregnancies were complicated by PPROM (Table 3).

Eighteen (94.7\%) and 81 (92.0\%) HIV-infected women in the PPROM and non-PPROM groups respectively received cART (OR 1.6; 95\%CI 0.2-13.4) (Table 4). HIVinfected women in the PPROM and non-PPROM groups did not differ significantly by CD4+ count (OR 1.3; 95\%CI 0.4-4.3) or HIV-1 viral load (OR 0.5; 95\%CI 0.11.9). At birth, HIV-1 PCR results were available for 22 of the 23 HIV-exposed babies in the PPROM group and 89 of the 90 babies in the non-PPROM group. None in the PPROM group and only one (1.1\%) HIV-exposed baby in the non-PPROM group tested positive at birth.

\section{Discussion}

In this most recent study in a high HIV endemic setting in South Africa, the preterm birth rate is approximately $17 \%$ and one in five of these preterm births is further complicated by prelabour rupture of membranes. HIV infection itself was not associated with increased risk of PPROM, and adverse birth outcomes. Gestational age at delivery and birth weight were not different in HIVinfected women compared to HIV-uninfected women whose pregnancies were complicated by PPROM. In addition, there was no evidence of increased mother-tochild transmission of HIV in women receiving cART and whose pregnancies were complicated by PPROM.

In current times when cART is the standard of care, we report a preterm delivery rate of $16.8 \%$, almost $50 \%$ were HIV-infected and $90 \%$ were on cART and virally suppressed. In a similar maternity audit at another local regional hospital in 2014, 32.2\% of all deliveries were classified as preterm (<37 weeks) [19]. At the time of the latter audit, only $45 \%$ of women were on cART prior to delivery. A reduction in preterm deliveries was reported for a rural setting in the region from $16.3 \%$ in 2010 to $9.3 \%$ in 2015 , and the reduction was attributed to the rollout of the cART program for pregnant women in the region [20]. The higher preterm delivery rate in our study is more likely due to the facility serving as a referral centre for high risk pregnancies in this urban region.

Almost one in five (19.9\%) of the preterm deliveries at this regional facility was further complicated by prelabour rupture of membranes, which translates to $2.67 \%$ (95\%CI 1.92-3.42) of all deliveries. Our incidence of PPROM (2.67\%) in 2018 in a high HIV endemic region in South Africa is similar to findings reported for the US (2.4\%) or France $(2-3 \%)$ where the antenatal HIV prevalence is markedly lower $[18,21]$. In the only other study conducted in KwaZulu Natal in 2013, prior to the cART rollout for pregnant women, 130 (1.69\%; 95\%CI $1.4-$ 1.98) of 7694 deliveries were complicated by PPROM [22]. Although intra-amniotic, urinary tract and sexually transmitted infections have long been identified as a cause of PPROM [23], our retrospective analysis did not allow for further exploration of the role of other infections in PPROM. We can however speculate the possible role of STIs in our study because this population is known for its high prevalence of STIs (32.3\%), mostly asymptomatic and could have likely contributed to the PPROM incidence in this population [24]. The STI study in the same population demonstrated the strong likelihood of an association between asymptomatic and untreated STIs and preterm births [24]. Another study 
Table 1 Characteristics of Women with and without Prelabour Rupture of Membranes at Preterm Delivery

\begin{tabular}{|c|c|c|c|c|}
\hline & $\begin{array}{l}\text { Prelabour Rupture of Membranes } \\
N=47\end{array}$ & $\begin{array}{l}\text { No Prelabour Rupture of Membranes } \\
N=189\end{array}$ & $\begin{array}{l}\text { Odds Ratio } \\
(95 \% \mathrm{Cl})\end{array}$ & $\begin{array}{l}p \\
\text { value }\end{array}$ \\
\hline Age (years) Mean (SD) & $26.9(6.6)$ & $26.4(6.8)$ & & 0.606 \\
\hline \multicolumn{5}{|l|}{ Category N (\%) } \\
\hline$\leq 19$ & $9(19.2)$ & $32(16.9)$ & & \multirow[t]{2}{*}{0.830} \\
\hline$>19$ & $38(80.8)$ & $157(83.1)$ & $1.2(0.5-2.6)$ & \\
\hline Parity Mean (SD) & $1.3 \pm 1.3$ & $1.3 \pm 1.3$ & & 0.607 \\
\hline \multicolumn{5}{|l|}{ Category N (\%) } \\
\hline 0 & $17(36.2)$ & $61(32.3)$ & \multirow[t]{2}{*}{$0.9(0.5-1.9)$} & \multirow[t]{2}{*}{1.000} \\
\hline$\geq 1$ & $30(63.8)$ & $128(67.7)$ & & \\
\hline \multicolumn{5}{|l|}{ Previous Pregnancy Complications N (\%) } \\
\hline Yes & $23(71.9)$ & $68(53.1)$ & \multirow[t]{2}{*}{$2.3(0.9-5.3)$} & \multirow[t]{2}{*}{0.072} \\
\hline No & $7(23.3)$ & $60(46.9)$ & & \\
\hline \multicolumn{5}{|l|}{ Antenatal Booking N (\%) } \\
\hline Yes & $42(89.4)$ & $175(93.6)$ & \multirow[t]{3}{*}{$0.7(0.2-2.3)$} & \multirow[t]{3}{*}{0.745} \\
\hline No & $5(10.6)$ & $12(6.4)$ & & \\
\hline Missing Data & - & 2 & & \\
\hline $\begin{array}{l}\text { Gestational Age at Booking (weeks) Mean } \\
\text { (SD) }\end{array}$ & $20.6 \pm 6.7$ & $18.5 \pm 7.4$ & & 0.103 \\
\hline \multicolumn{5}{|l|}{ Late ANC Booking ( $\geq 20 w k)$ N (\%) } \\
\hline Yes & $26(61.9)$ & 85 (48.6) & \multirow[t]{3}{*}{$1.7(0.9-3.4)$} & \multirow[t]{2}{*}{0.126} \\
\hline No & $16(38.1)$ & $90(51.4)$ & & \\
\hline Body Mass Index Mean (SD) & $29.3 \pm 7.8$ & $27.9 \pm 5.8$ & & 0.562 \\
\hline \multicolumn{5}{|l|}{ BMI Category N (\%) } \\
\hline$<30$ & $17(60.7)$ & $96(70.6)$ & \multirow[t]{3}{*}{$1.5(0.7-3.6)$} & \multirow[t]{3}{*}{0.370} \\
\hline$\geq 30$ & $11(39.3)$ & $40(29.9)$ & & \\
\hline Missing data & 9 & 53 & & \\
\hline \multicolumn{5}{|l|}{ History of Smoking N (\%) } \\
\hline Yes & $6(13.6)$ & $11(6.1)$ & \multirow[t]{3}{*}{$2.4(0.9-6.9)$} & \multirow[t]{3}{*}{0.111} \\
\hline No & $38(86.4)$ & $169(93.9)$ & & \\
\hline Missing data & 3 & 9 & & \\
\hline \multicolumn{5}{|l|}{ Alcohol Intake N (\%) } \\
\hline Yes & $3(6.8)$ & $16(8.9)$ & \multirow[t]{3}{*}{$0.8(0.2-2.7)$} & \multirow[t]{3}{*}{0.773} \\
\hline No & $41(93.2)$ & $164(91.1)$ & & \\
\hline Missing data & 3 & 9 & & \\
\hline \multicolumn{5}{|l|}{ HIV Infection N (\%) } \\
\hline Positive & $23(48.9)$ & $90(47.6)$ & \multirow[t]{3}{*}{$1.0(0.5-1.9)$} & \multirow[t]{3}{*}{1.000} \\
\hline Negative & $24(51.1)$ & $96(50.8)$ & & \\
\hline Unknown Status & & $3(1.6)$ & & \\
\hline Syphilis N (\%) & & & & \\
\hline Positive & $0(0)$ & $7(3.8)$ & - & 0.352 \\
\hline Negative & $43(100)$ & $177(96.2)$ & & \\
\hline Missing data & 4 & 5 & & \\
\hline
\end{tabular}


Table 2 Pregnancy Outcomes of Women with and without Prelabour Rupture of Membranes

\begin{tabular}{|c|c|c|c|c|}
\hline & $\begin{array}{l}\text { Prelabour Rupture } \\
\text { of Membranes } n=47\end{array}$ & $\begin{array}{l}\text { No Prelabour Rupture } \\
\text { of Membranes } n=189\end{array}$ & OddsRatio $(95 \% \mathrm{Cl})$ & $p$ value \\
\hline \multicolumn{5}{|l|}{ Mode of Delivery N (\%) } \\
\hline Spontaneous Vaginal & $25(53.2)$ & $86(46.2)$ & $0.7(0.4-1.3)$ & 0.320 \\
\hline Cesarean & $22(46.8)$ & $100(53.7)$ & & \\
\hline Missing data & 0 & 3 & & \\
\hline \multicolumn{5}{|l|}{ Birth Outcomes N(\%) } \\
\hline Stillbirth & $0(0)$ & $28(15.0)$ & - & 0.004 \\
\hline Livebirth & $47(100.0)$ & $159(85.0)$ & & \\
\hline Birth Weight (g) Mean (SD) & $2215(539)$ & $1944(676)$ & & 0.027 \\
\hline \multicolumn{5}{|l|}{ Category N (\%) } \\
\hline$<2500$ & $27(57.4)$ & $129(73.3)$ & $0.5(0.2-0.9)$ & 0.041 \\
\hline$\geq 2500$ & $20(42.56)$ & $46(26.7)$ & & \\
\hline Missing data & 0 & 4 & & \\
\hline $\begin{array}{l}\text { Gestational Age at Delivery-Weeks } \\
\text { Median (IQR) }\end{array}$ & $34(30-38)$ & $33(29-37)$ & & 0.139 \\
\hline \multicolumn{5}{|l|}{ Category N (\%) } \\
\hline$\leq 34$ & $21(44.7)$ & $128(68.1)$ & $0.6(0.3-1.1)$ & 0.122 \\
\hline$>34$ & $26(55.3)$ & $60(31.9)$ & & \\
\hline Missing data & 0 & 1 & & \\
\hline \multicolumn{5}{|l|}{ Newborn Apgar Score - 5 mins N (\%) } \\
\hline $8-10$ & $41(91.1)$ & $142(92.8)$ & $0.8(0.2-2.6)$ & 0.750 \\
\hline$<8$ & $4(8.9)$ & $11(7.2)$ & & \\
\hline Missing data & 2 & 6 & & \\
\hline
\end{tabular}

implicated the abnormal vaginal microbiome that is less dominated by Lactobaccilli sp. as a risk for PPROM [25]. Here again, BV testing is not routinely performed in our setting, but the high BV prevalence recently reported for this population needs further investigation for its role in preterm births and PPROM [26].

Our hypothesis that PPROM incidence is higher among HIV-infected women was not supported by our findings of similar high HIV positivity rates between women in the PPROM group and the non-PPROM group. Furthermore, the proportion of women on CART or with lower CD4 count or higher viral load was equally distributed among women with PPROM or without PPROM. The overall high HIV seroprevalence in our cohort is consistent with that reported in another PPROM study in the KZN region and the most recent national antenatal HIV survey [22, 27]. Unfortunately, the other KZN study lacked a control group of preterm deliveries without PPROM. From our study alone, it does not appear that HIV-infected women receiving CART were at a higher risk for preterm prelabour rupture of membranes.

Besides infection, other modifiable factors such as BMI and smoking have also been implicated as risk factors for PPROM. In our study, $22 \%$ of the women with preterm deliveries were obese but obesity was not characteristically unique to women with PPROM or non-PPROM. Our findings are supported by other studies that have confirmed that high BMI did not modify the risk for PPROM $[28,29]$. The study by Dekker et al. in New Zealand, however reported that a low BMI $(<20)$ nearly doubled the risk for PTB complicated by PPROM in nulliparous women [29]. While tobacco smoking is a known risk factor for PTB, smoking in our population is less common when compared to non-African populations, and although the proportion of women with a history of smoking was two-fold higher in the PPROM group than the non-PPROM group, this observation was not statistically significant [30].

In our study, women with PPROM were two times as likely to have had complications in a previous pregnancy than women without PPROM. The most common complications included preterm births (18.8\%), abruptio placentae (15.6\%) and preeclampsia (15.6\%) and these complications were more common among women with PPROM but not significantly different from the non-PPROM group. In a recent Thailand study, women with a history of preterm birth in a previous pregnancy were three times at higher risk of presenting with PPROM, while multiparity appeared to be protective against PPROM [31]. Our study sample size was limited, and we were unable to support or refute the Thailand findings. 
Table 3 Pregnancy Outcomes in HIVinfected and Uninfected Women with and without PPROM

\begin{tabular}{|c|c|c|c|c|}
\hline \multirow[b]{2}{*}{ HIV Status } & \multicolumn{2}{|c|}{ Prelabour Rupture of Membranes } & \multicolumn{2}{|c|}{ No Prelabour Rupture of Membranes } \\
\hline & Positive $(n=23)$ & Negative $(n=24)$ & Positive $(n=90)$ & Negative $(n=96)$ \\
\hline \multicolumn{5}{|l|}{ Mode of Delivery N (\%) } \\
\hline Spontaneous Vaginal & $13(56.5)$ & $12(50)$ & 37 (41.6) & $48(51.1)$ \\
\hline Cesarean & $10(43.5)$ & $12(50)$ & $52(58.4)$ & $46(48.9)$ \\
\hline $\begin{array}{l}\text { Odds Ratio }(95 \% \mathrm{Cl}) \\
\text { p Value }\end{array}$ & $\begin{array}{l}0.9(0.3-3.2) \\
1.000\end{array}$ & & $\begin{array}{l}0.7(0.4-1.2) \\
0.236\end{array}$ & \\
\hline \multicolumn{5}{|l|}{ Birth Outcomes N (\%) } \\
\hline Still Births & $0(0.0)$ & $0(0)$ & $15(16.9)$ & $15(15.8)$ \\
\hline Live Birth & $23(100)$ & $24(100)$ & $74(83.2)$ & $80(84.2)$ \\
\hline $\begin{array}{l}\text { Odds Ratio }(95 \% \mathrm{Cl}) \\
\text { p value }\end{array}$ & - & & $\begin{array}{l}0.9(0.4-2.1) \\
1.000\end{array}$ & \\
\hline \multicolumn{5}{|l|}{ Birth Weight (g) } \\
\hline Mean (SD) & $2180 \pm 499$ & $2246 \pm 583$ & $2050 \pm 674$ & $1842 \pm 661$ \\
\hline$p$ value & 0.796 & & 0.043 & \\
\hline \multicolumn{5}{|c|}{ Birth Weight by category N (\%) } \\
\hline$<2500$ & $14(60.9)$ & $13(54.2)$ & $58(67.4)$ & $69(80.2)$ \\
\hline$\geq 2500$ & $9(39.1)$ & $11(45.8)$ & $28(32.6)$ & $17(19.8)$ \\
\hline $\begin{array}{l}\text { Odds Ratio }(95 \% \mathrm{Cl}) \\
\text { p value }\end{array}$ & $\begin{array}{l}1.0(0.3-3.4) \\
1.000\end{array}$ & & $\begin{array}{l}0.5(0.3-1.0) \\
0.082\end{array}$ & \\
\hline \multicolumn{5}{|c|}{ Gestational Age at Delivery } \\
\hline Mean (SD) & $32.9 \pm 2.3)$ & $33.5 \pm 3.8)$ & $33.0 \pm 2.9$ & $32.4 \pm 2.9$ \\
\hline$p$ value & 0.113 & & 0.089 & \\
\hline \multicolumn{5}{|c|}{ Gestational Age by category N (\%) } \\
\hline$\leq 34$ weeks & $13(56.5)$ & $8(33.3)$ & $58(64.4)$ & $68(70.8)$ \\
\hline$>34$ weeks & $10(43.5)$ & $16(66.7)$ & $32(35.6)$ & $28(29.2)$ \\
\hline $\begin{array}{l}\text { Odds Ratio }(95 \% \mathrm{Cl}) \\
\text { p value }\end{array}$ & $\begin{array}{l}3.2(0.9-10.7) \\
0.080\end{array}$ & & $\begin{array}{l}0.8(0.4-1.4) \\
0.433\end{array}$ & \\
\hline \multicolumn{5}{|c|}{ Newborn Apgar Score - 5 mins N (\%) } \\
\hline $8-10$ & $20(90.9)$ & $21(91.3)$ & $70(95.9)$ & $69(89.6)$ \\
\hline$<8$ & $2(9.1)$ & $2(8.7)$ & $3(4.1)$ & $8(10.4)$ \\
\hline $\begin{array}{l}\text { Odds Ratio }(95 \% \text { Cl) } \\
\text { p value }\end{array}$ & $0.9(0.1-7.4) 1.000$ & & $2.7(0.7-10.6) 0.211$ & \\
\hline
\end{tabular}

Overall, birth outcomes in our study population were better in the PPROM group than the non-PPROM group. There were no stillbirths in the PPROM group and a significantly higher proportion of stillbirths among women without PPROM which could have been due to other obstetric complications such as maternal hypertensive disorders, antepartum haemorrhage or fetal invasive bacterial infection [32]. Similarly, despite no difference in the gestational age between both groups, the PPROM group had a significantly lower proportion of newborns weighing $<2500 \mathrm{~g}$. There was no evidence in our study of HIV contributing to worse pregnancy outcomes in the PPROM group. Although HIVinfected women with PPROM were two times as likely to deliver < 34 weeks when compared to their HIV-uninfected counterparts, this trend was not significant. There was a lower cesarean delivery rate among women with PPROM when compared to the non-PPROM group, and comparable between HIV-infected and uninfected women. Inconsistent with our high cesarean rate, the other KZN PPROM study reported a higher vaginal delivery rate among women with PPROM but did not compare this with other preterm deliveries [22]. Nonetheless, similar to our findings, there was no evidence of worse pregnancy and newborn outcomes among HIV-infected women with PPROM when compared to their HIV-uninfected counterparts [22]. As in our study, most HIV-infected women in the study by Msomi et al. were also on cART prior to delivery [22]. The other positive effect of cART in HIV-infected women in our cohort is evidenced by the zero mother-to-child transmission rate of HIV in the PPROM group, and only one case of in-utero transmission 
Table 4 HIV-Related Characteristics and Perinatal HIV Infection in association with PPROM

\begin{tabular}{|c|c|c|c|c|}
\hline & $\begin{array}{l}\text { Prelabour Rupture } \\
\text { of Membranes } \\
n=23\end{array}$ & $\begin{array}{l}\text { No } \\
\text { Prelabour } \\
\text { Rupture of } \\
\text { Membranes } \\
n=90\end{array}$ & $\begin{array}{l}\text { Odds } \\
\text { Ratio } \\
(95 \% \mathrm{Cl})\end{array}$ & $\begin{array}{l}p \\
\text { value }\end{array}$ \\
\hline \multicolumn{5}{|l|}{ Receiving cART n(\%) } \\
\hline Yes & $18(94.7)$ & $81(92.0)$ & $\begin{array}{l}1.6 \\
(0.2-13.4)\end{array}$ & 1.000 \\
\hline No & $1(5.3)$ & $7(8.0)$ & & \\
\hline Missing data & 4 & 2 & & \\
\hline CD4 Count Median (IQR) & $\begin{array}{l}369 \\
(333-656)\end{array}$ & $\begin{array}{l}508 \\
(325-659)\end{array}$ & & 0.368 \\
\hline \multicolumn{5}{|l|}{ CD4 Category N (\%) } \\
\hline$<350$ & $5(33.3)$ & $18(28.1)$ & & \\
\hline$\geq 350$ & $10(66.7)$ & $46(71.9)$ & $\begin{array}{l}1.3 \\
(0.4-4.3)\end{array}$ & 0.755 \\
\hline Missing data & 8 & 36 & & \\
\hline \multicolumn{5}{|l|}{ HIV Viral Load N(\%) } \\
\hline$<1000$ copies $/ \mathrm{ml}$ & $7(63.6)$ & $48(78.7)$ & & \\
\hline$\geq 1000$ copies $/ \mathrm{ml}$ & $4(36.4)$ & $13(21.3)$ & $\begin{array}{l}0.5 \\
(0.1-1.9)\end{array}$ & 0.440 \\
\hline Missing data & 12 & 29 & & \\
\hline \multicolumn{5}{|l|}{ Neonatal HIV PCR N (\%) } \\
\hline Negative & $22(100)$ & $88(98.9)$ & - & \\
\hline Positive & 0 & 1 & & \\
\hline Missing data & 1 & 1 & & \\
\hline
\end{tabular}

in the non-PPROM group. The neonate tested positive at birth, an indication of an in-utero infection. Our findings are supported by another study that reported women with PPROM on CART or HAART are less likely to transmit HIV infection to the infant [17]. This is in contrast to a US study conducted in the early 90's (pre-ARV era) that reported a four-fold increased risk of MTCT in women who developed PPROM [33].

\section{Study limitations}

Our sole reliance on data extracted from maternity records resulted in missing data for certain study participants but this was distributed equally among both PPROM and non-PPROM groups. The small proportion of PPROM cases was an additional limitation. A further limitation to our study was that we did not extend our observation to beyond the immediate postpartum period and hence neglected to include neonatal outcomes including perinatal HIV diagnosis after birth. We conducted this study at a regional hospital which also served as a referral centre for high risk pregnancies in the local area, hence our findings may not be generalizable to the larger population of the KZN.

\section{Conclusion}

In this most recent study of preterm deliveries in a high HIV endemic setting, there was no evidence of an association of PPROM with HIV infection, and neither were HIV-infected women who were receiving cART and who presented with PPROM at a higher risk for adverse pregnancy outcomes and MTCT. Based on our findings, it seems that standard management protocols for PPROM could remain unchanged for HIV-infected women on cART and virally suppressed.

\section{Abbreviations}

HIV: Human immunodeficiency virus; CART: combination antiretroviral treatment; PTB: Preterm birth; PPROM: Preterm prelabour rupture of membranes; KZN: KwaZulu Natal; HAART: Highly active antiretroviral treatment; MTCT: Mother-to-child transmission; BMI: Body mass index; PCR: Polymerase Chain Recation

\section{Acknowledgements}

We acknowledge the support of the hospital management of King Edward VIII Hospital, Durban in allowing us access to their maternity records.

\section{Authors' contributions}

CO conceptualised the study, interpreted the statistical analysis and wrote the manuscript. DM assisted in analysis of data, interpretation of statistical analysis and helped write the manuscript. NV assisted with conceptualising the study and reviewed the manuscript. MS assisted with interpretation of data and editing of the manuscript. The authors read and approved the final manuscript.

\section{Funding}

No funding was received for this work

Availability of data and materials

Dataset is available upon request.

Ethics approval and consent to participate

The study was approved by the Institutional Review Board of the University of KwaZulu-Natal. Consent to participate - not applicable. Gatekeeper permission was obtained from KEH to access data used in this analysis.

Consent for publication

Not applicable.

\section{Competing interests}

The authors declare no competing interests.

Received: 18 November 2019 Accepted: 30 March 2020

Published online: 09 April 2020

\section{References}

1. UNAIDS Global AIDS Update 2019. https://www.unaids.org/sites/default/ files/media_asset/UNAIDS_FactSheet en.pdf. Accessed 13 Mar 2020.

2. Chawanpaiboon S, Vogel JP, Moller AB, Lumbiganon P, Petzold M, Hogan D, et al. Global, regional, and national estimates of levels of preterm birth in 2014: a systematic review and modelling analysis. Lancet Glob Health. 2019;7(1):e37-46. https://doi.org/10.1016/S2214109X(18)30451-0 Epub 2018 Oct 30.

3. Blencowe $H$, Cousens $S$, Oestergaard MZ, Chou D, Moller AB, Narwal $R$, et al. National, regional, and worldwide estimates of preterm birth rates in the year 2010 with time trends since 1990 for selected countries: a systematic analysis and implications. Lancet. 2012;379(9832):2162-72.

4. Goldenberg RL, Culhane JF, lams JD, Romero R. Epidemiology and causes of preterm birth. Lancet. 2008;371(9606):75-84. https://doi.org/10.1016/S01406736(08)60074-4 Review.

5. Mercer BM. Preterm premature rupture of the membranes. Obstet Gynecol. 2003;101(1):178-93. 
6. American College of Obstetricians and Gynecologists' Committee on Practice Bulletins-Obstetrics. Practice Bulletin No. 172: premature rupture of membranes. Obstet Gynecol. 2016;128(4):e165-77.

7. Menon R, Richardson LS. Preterm prelabor rupture of the membranes: a disease of the fetal membranes. Semin Perinatol. 2017;41(7):409-19.

8. England MC, Benjamin A, Abenhaim HA. Increased risk of preterm premature rupture of membranes at early gestational ages among maternal cigarette smokers. Am J Perinatol. 2013;30(10):821-6.

9. Benedetto C, Tibaldi C, Marozio L, Marini S, Masuelli G, Pelissetto S, Sozzani P, Latino MA. Cervicovaginal infections during pregnancy: epidemiological and microbiological aspects. J Matern Fetal Neonatal Med. 2004;16(Suppl 2): 9-12.

10. Lopez M, Figueras F, Hernandez S, Lonca M, Garcia R, Palacio M, Coll O. Association of HIV infection with spontaneous and iatrogenic preterm delivery: effect of HAART. AIDS. 2012;26(1):37-43.

11. Deressa AT, Cherie A, Belihu TM, Tasisa GG. Factors associated with spontaneous preterm birth in Addis Ababa public hospitals, Ethiopia: cross sectional study. BMC Pregnancy Childbirth. 2018;18(1):332. https:/doi.org/ 10.1186/s12884-018-1957-0.

12. Xiao $P L$, Zhou $Y B$, Chen $Y$, Yang MX, Song XX, Shi Y, Jiang QW. Association between maternal HIV infection and low birth weight and prematurity: a meta-analysis of cohort studies. BMC Pregnancy Childbirth. 2015;15:246.

13. Obimbo MM, Zhou Y, McMaster MT, Cohen CR, Qureshi Z, Ong'ech J, Ogeng'o JA, Fisher SJ. Placental structure in preterm birth among HIVpositive versus HIV-negative women in Kenya. J Acquir Immune Defic Syndr. 2019;80(1):94-102. https://doi.org/10.1097/QAl.0000000000001871.

14. Naidoo M, Sartorius B, Tshimanga-Tshikala G. Maternal HIV infection and preterm delivery outcomes at an urban district hospital in KwaZulu-Natal 2011. South Afr J Infect Dis. 2016;31(1):25-8.

15. Garcia-Tejedor A, Perales A, Maiques V. Duration of ruptured membranes and extended labor are risk factors for HIV transmission. Int J Gynaecol Obstet. 2003;82(1):17-23.

16. Biggar RJ, Miotti PG, Taha TE, Mtimavalye L, Broadhead R, Justesen A, Yellin F, Liomba G, Miley W, Waters D, Chiphangwi JD, Goedert JJ. Perinatal intervention trial in Africa: effect of a birth canal cleansing intervention to prevent HIV transmission. Lancet. 1996:347(9016):1647-50.

17. Alvarez JR, Bardeguez A, Iffy L, Apuzzio JJ. Preterm premature rupture of membranes in pregnancies complicated by human immunodeficiency virus infection: a single center's five-year experience. J Matern Fetal Neonatal Med. 2007;20(12):853-7.

18. Aagaard-Tillery KM, Lin MG, Lupo V, Buchbinder A, Ramsey PS. Preterm premature rupture of membranes in human immunodeficiency virusinfected women: a novel case series. Infect Dis Obstet Gynecol. 2006;2006: 53234.

19. Moodley T, Moodley D, Sebitloane M, Maharaj N, Sartorius B. Improved pregnancy outcomes with increasing antiretroviral coverage in South Africa. BMC Pregnancy Childbirth. 2016;16:35. https://doi.org/10.1186/s12884-0160821-3.

20. Chetty T, Thorne C, Coutsoudis A. Preterm delivery and small-for-gestation outcomes in HIV-infected pregnant women on antiretroviral therapy in rural South Africa: results from a cohort study, 2010-2015. PLoS One. 2018;13(2): e0192805. https://doi.org/10.1371/journal.pone.0192805 eCollection 2018.

21. Schmitz T, Sentilhes L, Lorthe E, Gallot D, Madar H, Doret-Dion M, et al. Preterm premature rupture of membranes: CNGOF guidelines for clinical practice. Gynecol Obstet Fertil Senol. 2018;46(12):998-1003.

22. Msomi G, Naidoo M, Hira B. Perinatal outcomes in pregnant women presenting with preterm premature rupture of membranes at a regional hospital in KwaZulu-Natal Province, South Africa. S Afr J Obstet Gynaecol. 2017;23(2):43-7.

23. Ekwo EE, Gosselink CA, Woolson R, Moawad A. Risks for premature rupture of amniotic membranes. Int J Epidemiol. 1993;22(3):495-503.

24. Moodley D, Moodley P, Sebitloane M, Soowamber D, McNaughton-Reyes $\mathrm{HL}$, Groves AK, Maman S. High prevalence and incidence of asymptomatic sexually transmitted infections during pregnancy and postdelivery in KwaZulu Natal, South Africa. Sex Transm Dis. 2015;42(1):43-7.

25. Brown RG, Al-Memar M, Marchesi JR, Lee YS, Smith A, Chan D, et al. Establishment of vaginal microbiota composition in early pregnancy and its association with subsequent preterm prelabor rupture of the fetal membranes. Transl Res. 2019;207:30-43.

26. Joyisa N, Moodley D, Nkosi T, Talakgale R, Sebitloane M, Naidoo M, Karim QA. Asymptomatic bacterial Vaginosis in pregnancy and missed opportunities for treatment: a cross-sectional observational study. Infect Dis Obstet Gynecol. 2019;2019:7808179. https://doi.org/10.1155/2019/7808179 eCollection 2019.

27. Woldesenbet S, Kufa T, Lombard C, Manda S, Ayalew K, Cheyip M, Puren A. Key Findings of the 2017 South Afrucan Antenatal HIV Sentinel Survey (ANCHSS). http://www.nicd.ac.za/wp-content/uploads/2019/10/KEYFINDINGS-OF-THE-2017-SOUTH-AFRICAN-ANTENATAL-HIV-SENTINEL-SURVEYANCHSS_NICD-Bulletin-Vol17-Iss2-October2019.pdf. Accessed 13 Mar 2020.

28. Torloni MR, Betrán AP, Daher S, Widmer M, Dolan SM, Menon R, et al. Maternal BMI and preterm birth: a systematic review of the literature with meta-analysis. J Matern Fetal Neonatal Med. 2009;22(11):957-70.

29. Dekker GA, Lee SY, North RA, McCowan LM, Simpson NA, Roberts CT. Risk factors for preterm birth in an international prospective cohort of nulliparous women. PLoS One. 2012;7(7):e39154. https://doi.org/10.1371/ journal.pone.0039154 Epub 2012 Jul 16.

30. Ion R, Bernal AL. Smoking and preterm birth. Reprod Sci. 2015;22(8):918-26.

31. Sae-Lin $P$, Wanitpongpan $P$. Incidence and risk factors of preterm premature rupture of membranes in singleton pregnancies at Siriraj hospital. J Obstet Gynaecol Res. 2019;45(3):573-7.

32. Madhi SA, Briner C, Maswime S, Mose S, Mlandu P, Chawana R, et al. Causes of stillbirths among women from South Africa: a prospective, observational study. Lancet Glob Health. 2019;7(4):e503-12. https://doi.org/10.1016/S2214109X(18)30541-2.

33. Burns DN, Landesman S, Muenz LR, Nugent RP, Goedert JJ, Minkoff H, et al. Cigarette smoking, premature rupture of membranes, and vertical transmission of HIV-1 among women with low CD4+ levels. J Acquir Immune Defic Syndr. 1994;7(7):718-26.

\section{Publisher's Note}

Springer Nature remains neutral with regard to jurisdictional claims in published maps and institutional affiliations.
Ready to submit your research? Choose BMC and benefit from:

- fast, convenient online submission

- thorough peer review by experienced researchers in your field

- rapid publication on acceptance

- support for research data, including large and complex data types

- gold Open Access which fosters wider collaboration and increased citations

- maximum visibility for your research: over $100 \mathrm{M}$ website views per year

At $\mathrm{BMC}$, research is always in progress.

Learn more biomedcentral.com/submissions 